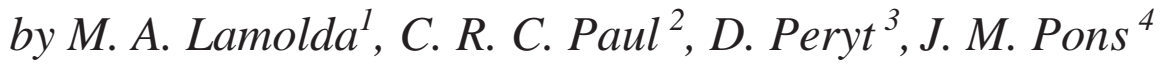

\title{
The Global Boundary Stratotype and Section Point (GSSP) for the base of the Santonian Stage, "Cantera de Margas", Olazagutia, northern Spain
}

\author{
1 Depto. de Estratigrafía y Paleontología, Facultad de Ciencias-Univ. de Granada, Avda. de Fuentenueva s/n, 18002, Granada, Spain. \\ 2 School of Earth Sciences, University of Bristol, Wills Memorial Bldg, Queen’s Road, Bristol, BS8 1RJ, U.K. E-mail: glcrcp@bris.ac.uk \\ 3 Instytut Paleobiologii, Polska Akademia Nauk, ul. Twarda 51/55, PL- 00-818 Warszawa, Poland. \\ 4 Departament de Geologia, Universitat Autònoma de Barcelona, E-08193 Bellaterra, Spain.
}

The GSSP for the base of the Santonian Stage is defined at $94.4 \mathrm{~m}$ in the eastern border of the "Cantera de Margas" quarry, Olazagutia (Navarra, N. Spain: $42^{\circ}$ $52^{\prime} 05.3^{\prime \prime} \mathrm{N}, 2^{\circ} 11^{\prime} 40^{\prime \prime} \mathrm{W}$ ) and marked by the first occurrence (FO) of the inoceramid bivalve Platyceramus undulatoplicatus. This first occurrence is located about $9 \mathrm{~m}$ below the contact between a lower marly unit and an upper more calcareous unit. The FO of the planktonic foraminifer Sigalia carpatica is the secondary marker of the GSSP and first occurs $7 \mathrm{~m}$ below the primary marker, but it becomes consistently present about $4.2 \mathrm{~m}$ above the boundary. In addition, six peaks in the carbon stable isotope curve can be recognized between the Kingsdown Event $17.2 \mathrm{~m}$ below and the Bedwell Event $12.35 \mathrm{~m}$ above the GSSP. The basal Santonian GSSP was approved by the International Subcommission on Cretaceous Stratigraphy in September 2010, by the International Commision of Stratigraphy in April 2012, and ratified by the International Union of Geological Sciences in January 2013.

\section{Introduction}

The Santonian Stage was proposed by Coquand (1857), presumably named after the town of Saintes in south-west France. One of the localities mentioned by Coquand was Javrezac, a village on the north-west side of Cognac. The boundary there was drawn on a hardground between glauconitic, nodular limestone, with many Exogyra of the Coniacian below, and soft micaceous chalk of the Santonian above.

At the First Symposium on Cretaceous Stage Boundaries (Birkelund et al. 1984) the consensus was that the first occurrences (FO) of the ammonite subgenus Texanites (Texanites) and of the inoceramid bivalve Cladoceramus (=Platyceramus) undulatoplicatus (Roemer) were the two best boundary criteria. Texanites (Texanites) had been used over a wide area, although in classic regions of northwest Europe this subgenus is far too rare to be a practical marker
(Hancock, 1991). Platyceramus undulatoplicatus is widespread and on account of its characteristic form and sculpture, is easy to identify. In N. Africa Platyceramus siccensis (Pervinquière) is associated with Texanites, and was considered another possible marker for the base of the Santonian.

In the Santonian Working Group report to the second Symposium on Cretaceous Stage Boundaries (Lamolda and Hancock, 1996) the FO of Platyceramus undulatoplicatus was confirmed as the primary marker for the base of the Santonian Stage. The FO of Texanites (Texanites) was rejected because it occurs below the lowest Platyceramus undulatoplicatus and had been cited in assemblages with inoceramids normally regarded as Coniacian (Lamolda and Hancock 1996). The FO of the planktonic foraminifer Sigalia carpatica was accepted as a secondary marker for the basal Santonian. It is widespread in the Mediterranean region of the Tethys, is associated with Inoceramus siccensis and Texanites in Tunisia, and in northern Spain (Navarra) its FO is very close to the lowest occurrence of Platyceramus undulatoplicatus. Three sections were approved as candidate GSSPs; Olazagutia Quarry (Navarra, Spain), Seaford Head (Sussex, England) and Ten Mile Creek (Dallas, Texas). Results were published in a special issue of Cretaceous Research "Stratigraphy of the Coniacian-Santonian transition" (vol. 28 no. 1, 2007; Gallemí et al., Howe et al., Lamolda and Paul, Lamolda et al., Peryt and Lamolda), and another paper in Acta Geologica Polonica (Gale et al., 2007). The Olazagutia section was chosen as the GSSP by the Santonian Working Group in November 2007 and approved by the International Subcommission on Cretaceous Stratigraphy in September 2010. This decision was finally approved by the International Commission of Stratigraphy in April 2012, and ratified by the International Union of Geological Sciences in January 2013.

\section{The "Cantera de Margas" Section}

The Olazagutia section is located in the Basque-Cantabrian Region (BCR) of northern Spain, to the west of the Pyrenees (Fig. 1). During the Late Cretaceous the area around Olazagutia was a distal part of the Navarro-Cantabrian Platform, except in the Maastrichtian when a proximal ramp with shallow-water facies was established. The platform is subdivided by both longitudinal (NW-SE) and transverse (NE-SW) faults. In spite of local and/or temporary fluctuations, the platform remained typically an outer shelf environment where deposits 


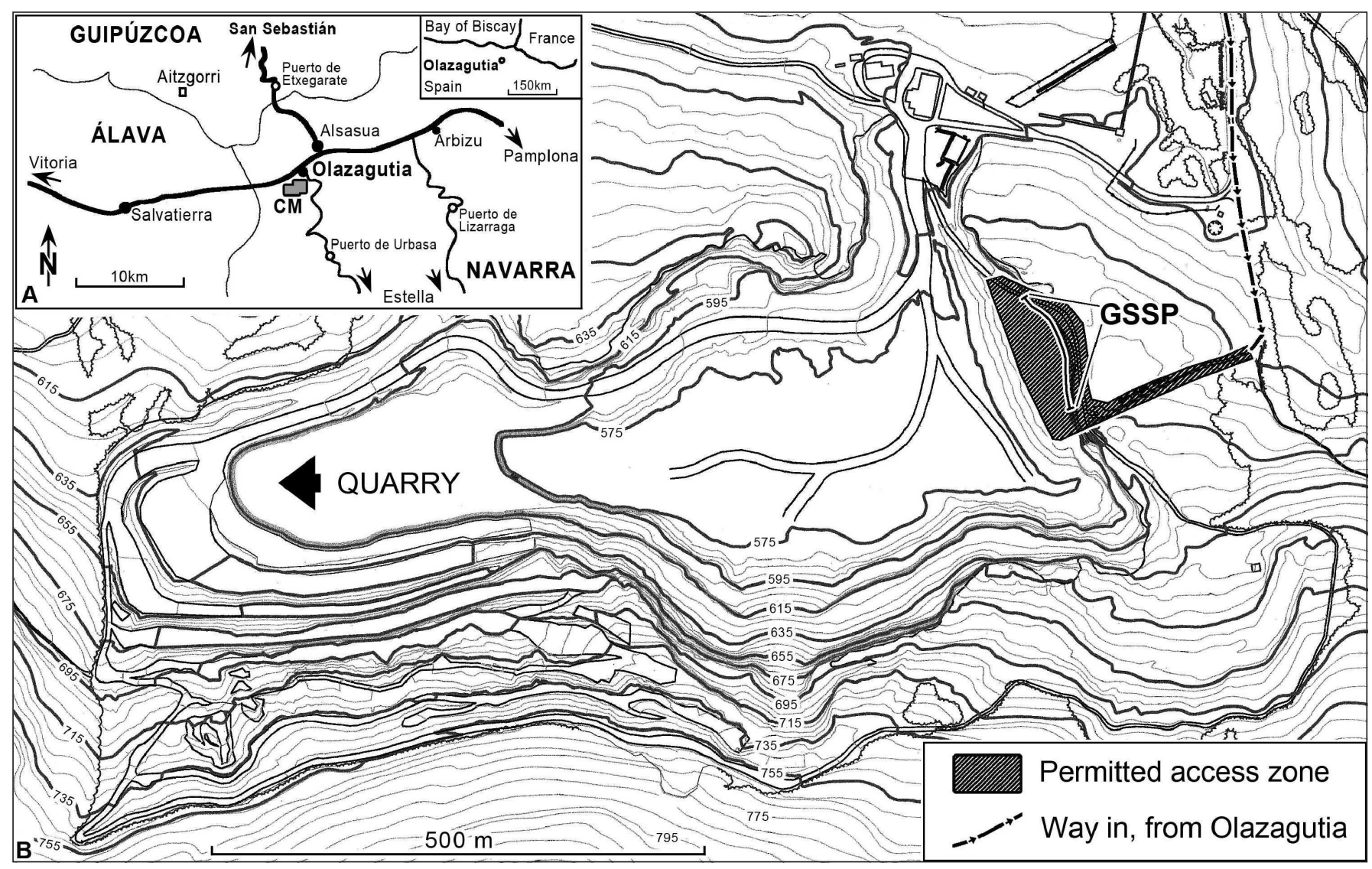

Figure 1. A Location of the Olazagutia section in northern Spain. CM = Cantera de Margas (after Lamolda and Paul, 2007, fig. 1). B The section studied along the eastern side of the Cantera de Margas and the permitted access.

are mainly fine pelitic sediments (Amiot et al., 1983; Wiedmann et al., 1983; Gallemí et al., 2007).

In the area studied both the Coniacian and Santonian consist of intercalated marls and marly limestones. The thickness of Coniacian strata is estimated to be 400-600 m (Ramírez del Pozo, 1971; Zander, 1988). Kannenberg (1985) estimated the thickness of the Santonian strata in the "Cantera de Margas" at Olazagutia to be about $230 \mathrm{~m}$.

The section is located in a working quarry to the south of Olazagutia, Navarra, Spain (Fig. 1). Its geographical location is $42^{\circ} 52^{\prime}$ 05.3" N, 2 11' 40" W; Lambert Coordinates 919, 722, 1:25000 topographic sheet no. 113-4 Olazagutia.

Further details on the general stratigraphy around Olazagutia are given by Küchler (2002). A general overview of Upper Cretaceous sequence stratigraphy of the BCR was given by Gräfe and Wiedmann (1998), who defined the boundary between cycles UC11 and UC12 above, but close to, the current Coniacian/Santonian boundary (CSB).

\section{Lithostratigraphy}

The section along the disused eastern side of the Cantera de Margas quarry exposes ca. $160 \mathrm{~m}$ of marls and marly limestones and extends from the middle Coniacian to the middle Santonian. The lower, more marly part is referred to the La Barranca Member of the El Zadorra Formation; the higher part to the Olazagutia Formation (Fig. 2), as defined by Amiot (1982). A part of the section has been studied in more detail, on a ramp into the middle level of the quarry, and belongs to the lower part of the Olazagutia Formation (Figs. 3-5).
Thin $(10-20 \mathrm{~cm})$ limestone beds occur from ca. $20 \mathrm{~m}$ below to $9 \mathrm{~m}$ above the Coniacian/Santonian boundary (as defined by the FO of P. undulatoplicatus), which occurs at $94.4 \mathrm{~m}$ above the base of the section (Fig. 4). Higher up, more uniform and thicker-bedded limestones occur. Marcasite nodules, often rusty-weathered, occur from ca. 7-14 $\mathrm{m}$ above the boundary. There are also very weak hints of at least five larger-scale cycles ca. $10 \mathrm{~m}$ thick, each starting with rather thicker chalk beds in the boundary interval that we studied. The base of the lowest cycle lies in the covered interval below our section and has been used to define the boundary between the Zadorra and Olazagutia formations (Amiot, 1982).

Macrofossils are sufficiently common in parts of the section to contribute to the lithological characteristics of the beds. They are rare at the base of the section, but echinoids and inoceramid bivalves occur sporadically in the first $75 \mathrm{~m}$ or so. Echinoids are particularly abundant in the $12 \mathrm{~m}$ below the boundary, and are fairly common up to at least $20 \mathrm{~m}$ above it (Fig. 3). Inoceramids, especially P. undulatoplicatus, appear abundantly at the boundary (Fig. 3). Platyceramus undulatoplicatus is very common in the first $2 \mathrm{~m}$, is then sporadic for nearly $10 \mathrm{~m}$, with its higher occurrence about 11.5 $\mathrm{m}$ above the boundary. Sponges (sometimes iron-rich and rustyweathered) occur both sporadically and in distinct sponge-rich beds from $2.5 \mathrm{~m}$ below to $15 \mathrm{~m}$ above the boundary (Fig. 3).

\section{Biostratigraphy}

Inoceramids, planktonic foraminifera and calcareous nannofossils can be used to define biostratigraphic zones across the boundary 


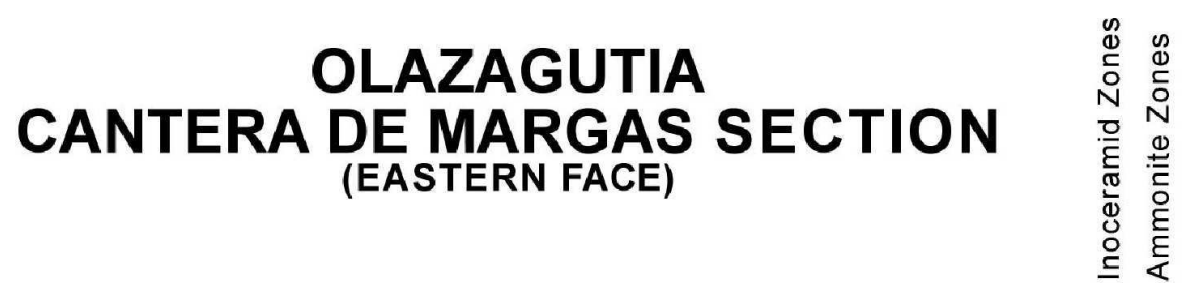

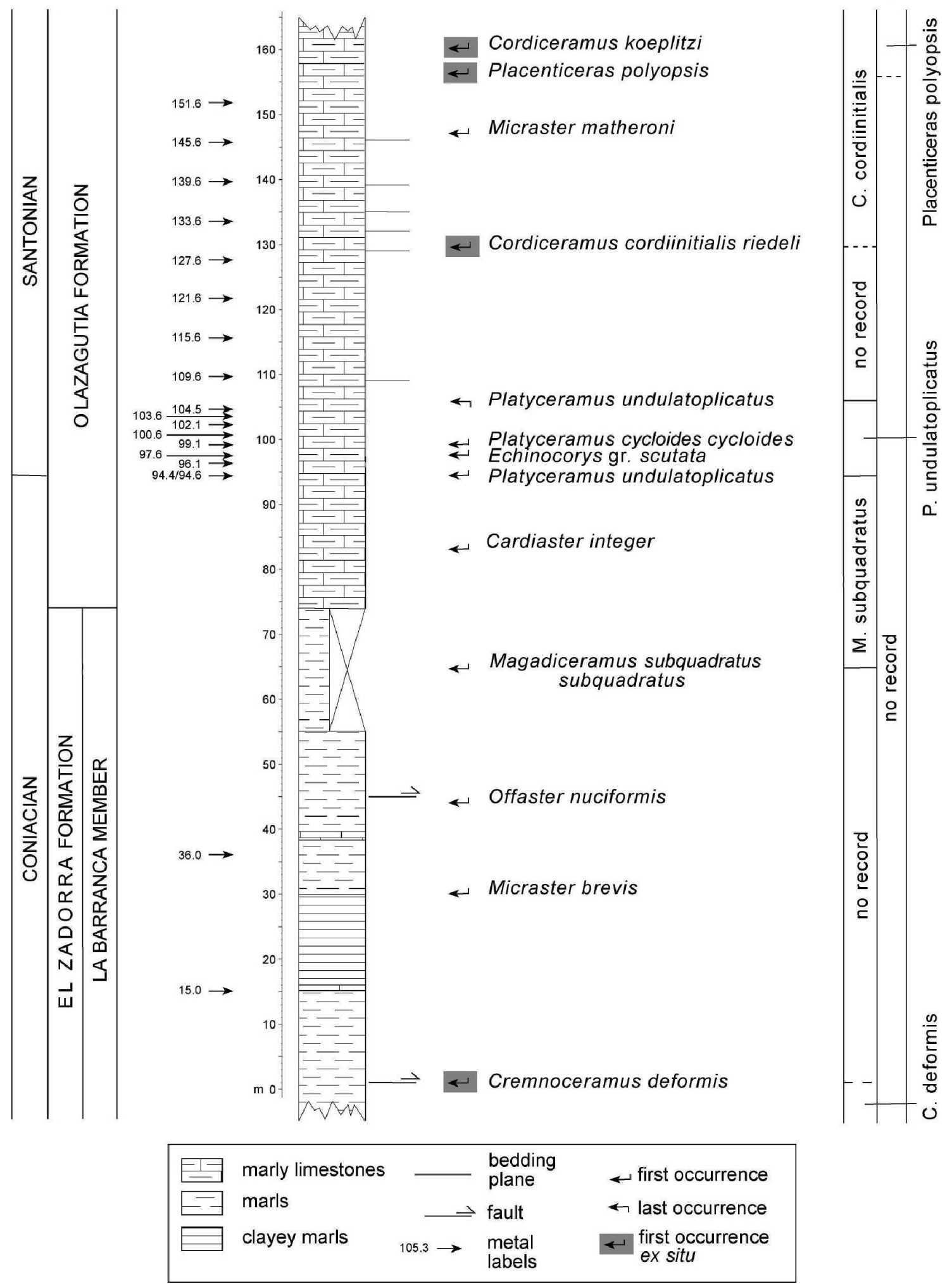

Figure 2. The Olazagutia section, with indication of main first and last occurrences (FO and LO) of inoceramid, echinoid and ammonite taxa (after Gallemí et al., 2007, fig. 5). 


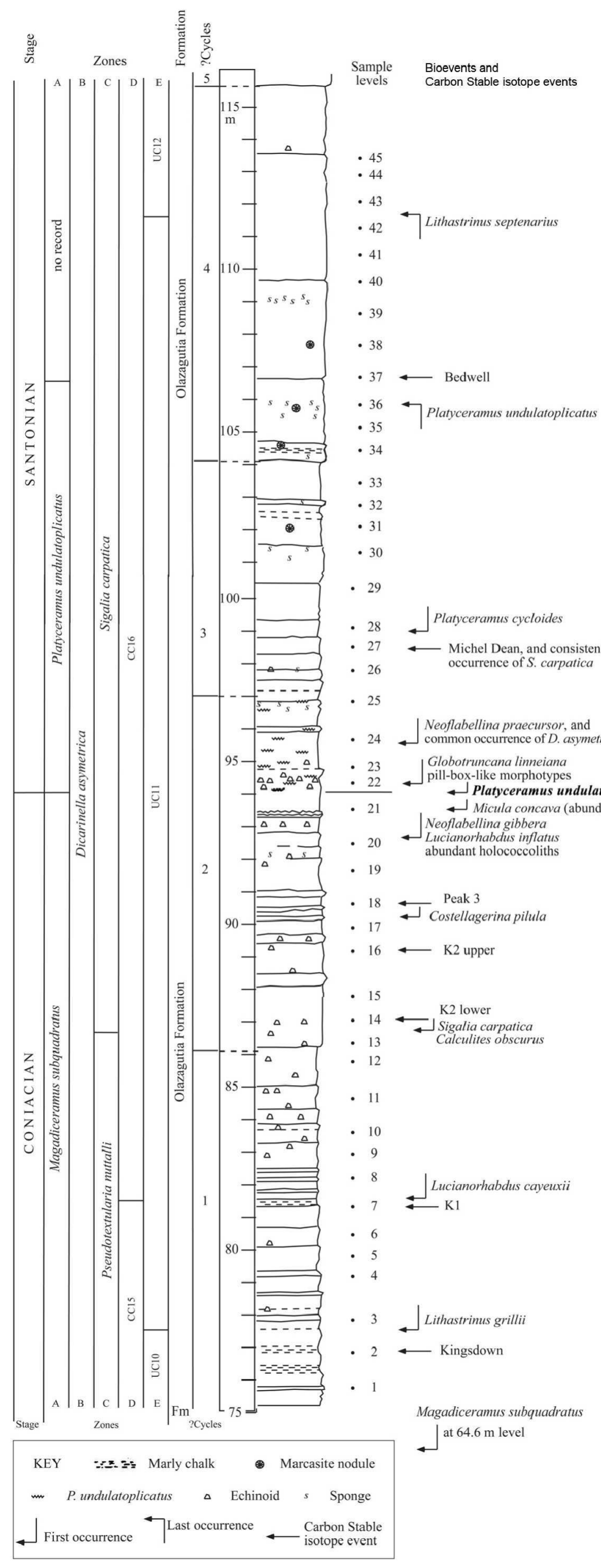

(Fig. 3), but at Olazagutia ammonites first appear well above the boundary (Gallemí et al., 2007).

\section{Inoceramid bivalves}

Inoceramids occur discontinuously, although they are abundant in the upper half of the section. The first examples of Magadiceramus occur at $64.6 \mathrm{~m}$, ca. $11 \mathrm{~m}$ below the base of our studied section, and indicate the presence of the $M$. subquadratus Zone of late Coniacian age. Platyceramus undulatoplicatus first appears at $94.4 \mathrm{~m}$ and defines both the base of the eponymous zone and the Santonian Stage (Fig. 3). It occurs through a total range of $11.5 \mathrm{~m}$. Almost certainly, the lowermost and uppermost levels correspond to inoceramid events 1 and 2 of the Kent coast in England (Jenkyns et al., 1994; Jarvis et al., 2006). Both the FO and LO are reliable bioevents, that is, they plot very close to the best fit lines in graphic correlation between all pairs of sections so far investigated (Paul and Lamolda 2009). Platyceramus cycloides subspp. and Cordiceramus spp. are commonly recorded in the lower part of the Santonian. Details of macrofossils recorded at Olazagutia are given in Fig. 2 (after Gallemí et al., 2007).

\section{Planktonic Foraminifera}

The main planktonic taxa belong to keeled, trochospiral species of genera such as Contusotruncana, Dicarinella, Globotruncana and Marginotruncana. The most abundant components are biconvex species of Marginotruncana. Planktonic foraminiferal assemblages found in the samples studied enable recognition of biozonations based on globotruncanids and heterohelicids (Fig. 6). Dicarinella asymetrica (Sigal) occurs throughout the section studied (Lamolda et al., 2007), which thereby belongs entirely to the Dicarinella asymetrica Zone. Heterohelicid species are also useful for biozonation. The first occurrence of Sigalia carpatica Salaj and Samuel is located ca. $7 \mathrm{~m}$ below the first occurrence of Platyceramus undulatoplicatus, and is used to characterize the lower boundary of the eponymous biozone, following Nederbragt's (1990) biozonation. The underlying sediments belong to the Pseudotextularia nuttalli Zone. More details on planktonic foraminifera are given in Lamolda et al. (2007), and below under the overview of main fossil groups.

\section{Nannofossils}

Melinte and Lamolda (2002) studied nannofloral assemblages, which belong to nannofossil zones CC15-CC16 of Sissingh (1977), and calcareous nannofossil zones UC10UC12 of Burnett (1998), respectively (Fig. 7). A succession of bioevents characterizes the CSB interval in the section studied (Fig. 3). Of special note is the local first occurrence of Lucianorhabdus inflatus Perch-Nielsen and Feinberg,

Figure 3. The sequence of events across the Coniacian/Santonian transition in the Cantera de Margas, eastern border section, Olazagutia, northern Spain (modified after Lamolda and Paul, 2007, fig. 2). 


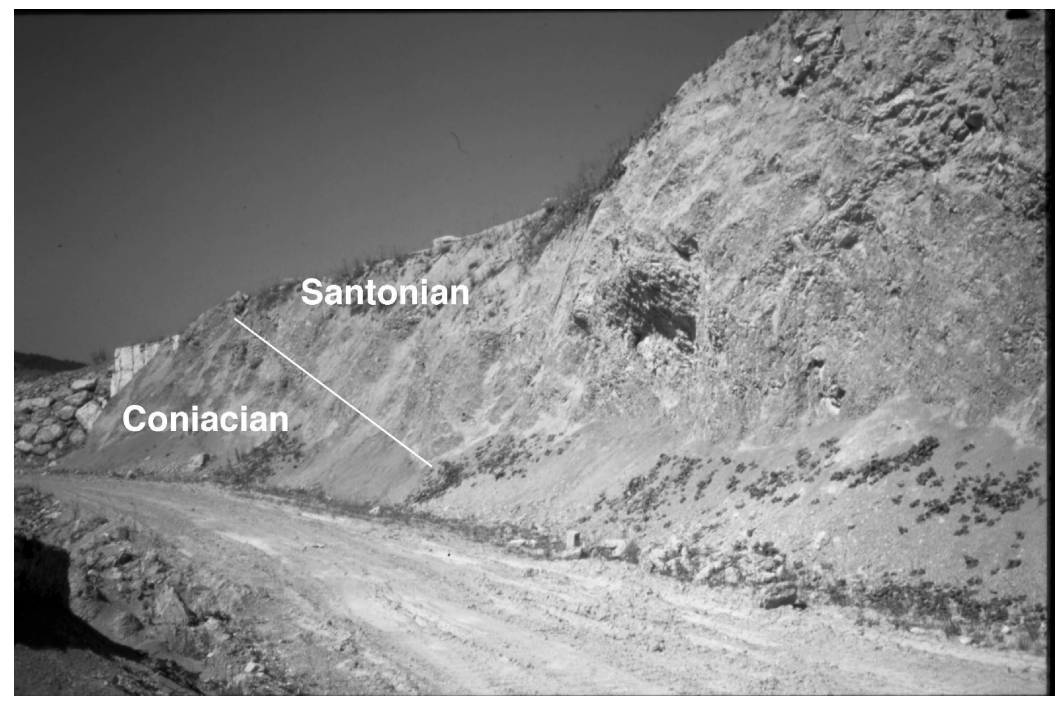

Figure 4. A general view of the Cantera de Margas section. The approximate location of the Coniacian/Santonian boundary is shown by the white line.

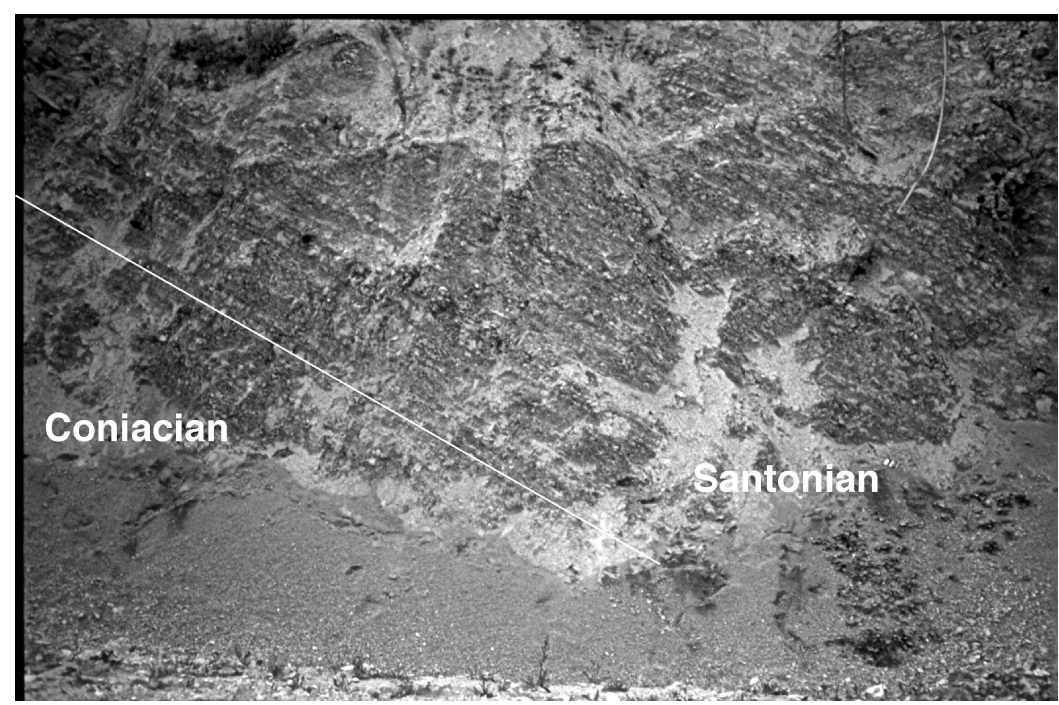

Figure 5. The Coniacian/Santonian transition at the Cantera de Margas section. The level of the FO of P. undulatoplicatus is marked by the white line.

which is very close to the base of the Santonian ( $1.75 \mathrm{~m}$ below), as in the Romanian Carpathians (Melinte and Lamolda, 2007). Other nannofossil events observed in the succession at Olazagutia are high abundances of Lucianorhabdus spp. and Micula concava (Stradner) Verbeek in the CSB interval, followed by the increasing abundance of Calculites within the lowermost Santonian (Melinte and Lamolda, 2002). Further comments are given below. Illustrations of the calcareous nannofossils mentioned can be found in Lamolda et al. (1999) and Perch-Nielsen (1985).

\section{Stable Isotopes}

Carbon isotope values across the Coniacian/Santonian boundary only vary by a maximum of $0.37 \%$ o (Fig. 8). There is no major excursion, such as occurs across the Cenomanian/Turonian boundary. Nevertheless, they do show a gradual and continuous decline through the sampled interval from a maximum of $+3.05 \%$ (sample 2 ) to $+2.68 \%$ ( sample 45 ), with some fluctuations (Fig. 8). In particular, there is a relatively large drop from 2.98 to $2.71 \%$ over four samples just below the first appearance of $P$. undulatoplicatus. Above this level values increase again to $2.91 \%$ o over the next four samples.

Results from Olazagutia were originally compared (Lamolda and Paul, 2007) with the carbon isotope curve of Jenkyns et al. (1994) for east Kent (Fig. 8) and later (Paul and Lamolda 2009) with the carbon isotope curves of Jarvis et al. (2006) for southern England (Fig. 9), since the first and last occurrences (FO and LO) of $P$. undulatoplicatus are recorded in both places. We used the total ranges of $P$. undulatoplicatus to estimate relative sedimentation rates at both localities and adjusted the scales of the sections accordingly to produce our correlation (Fig. 9). Both carbon isotope curves lack major excursions, but do show similar features. In both, carbon isotope values decline across the Coniacian/Santonian boundary, with one or two brief reversals. In particular, three minima (the late Coniacian, at the boundary, and in the early Santonian) can be recognized in both curves.

Using the total thickness of the Coniacian and Santonian in east Kent (Jenkyns et al., 1994, fig. 13), the time scale of Harland et al. (1989) and our best correlation (Fig. 9), Paul and Lamolda (2009) estimated that the mean sampling interval at Olazagutia was approximately 22,000 years. Within the limits of our sampling, $\delta^{13} \mathrm{C}$ curves and the total range of $P$. undulatoplicatus gave equally accurate correlations (Paul and Lamolda 2009). This, in turn, confirms that the first occurrence of $P$. undulatoplicatus is a very good primary marker for the Coniacian/Santonian boundary, at least in western Europe. Further comments are given below in an overview of carbon stable isotopes.

\section{Palaeobiogeography}

Palaeogeographic reconstructions of the region around the CSB provide a $30^{\circ} \mathrm{N}$ palaeolatitude for northern Spain (around $42^{\circ} \mathrm{N}$ at present). This part of the northern Tethys had direct communications with the North Atlantic to the west, and the London-Paris basin to the north. It was part of the palaeotropics but with influences of the northern temperate regions.

Most of the nannofossils occurring around the CSB interval herein are cosmopolitan taxa, although a small number of them are more closely related to low- than to high latitudes. A significant component of the nannofloras from the Olazagutia section is Watznaueria barnesae, the most abundant Cretaceous cosmopolitan nannofossil. Concerning this taxon, Thierstein (1981) indicated that it showed a latitudinal distribution pattern, being more common at low latitudes, becoming less abundant towards higher latitudes, although still forming an important component of high-latitude nannofloral assemblages. The presence of the nannofossils Lithastrinus grillii and Lithastrinus septenarius, both identified in the Olazagutia section, indicates, according to Varol (1992), warm to temperate waters of low-mid latitudes. Another important component of the assemblages identified in the studied section is the genus Nannoconus, which reached, at certain levels, $>15 \%$ of the nannofloral assemblage. Interestingly, the abundance of nannoconids sharply decreases below the Coniacian/Santonian boundary, almost coincident with a minimum in the $\delta^{13} \mathrm{C}$ curve. It is noteworthy that the Upper Cretaceous 


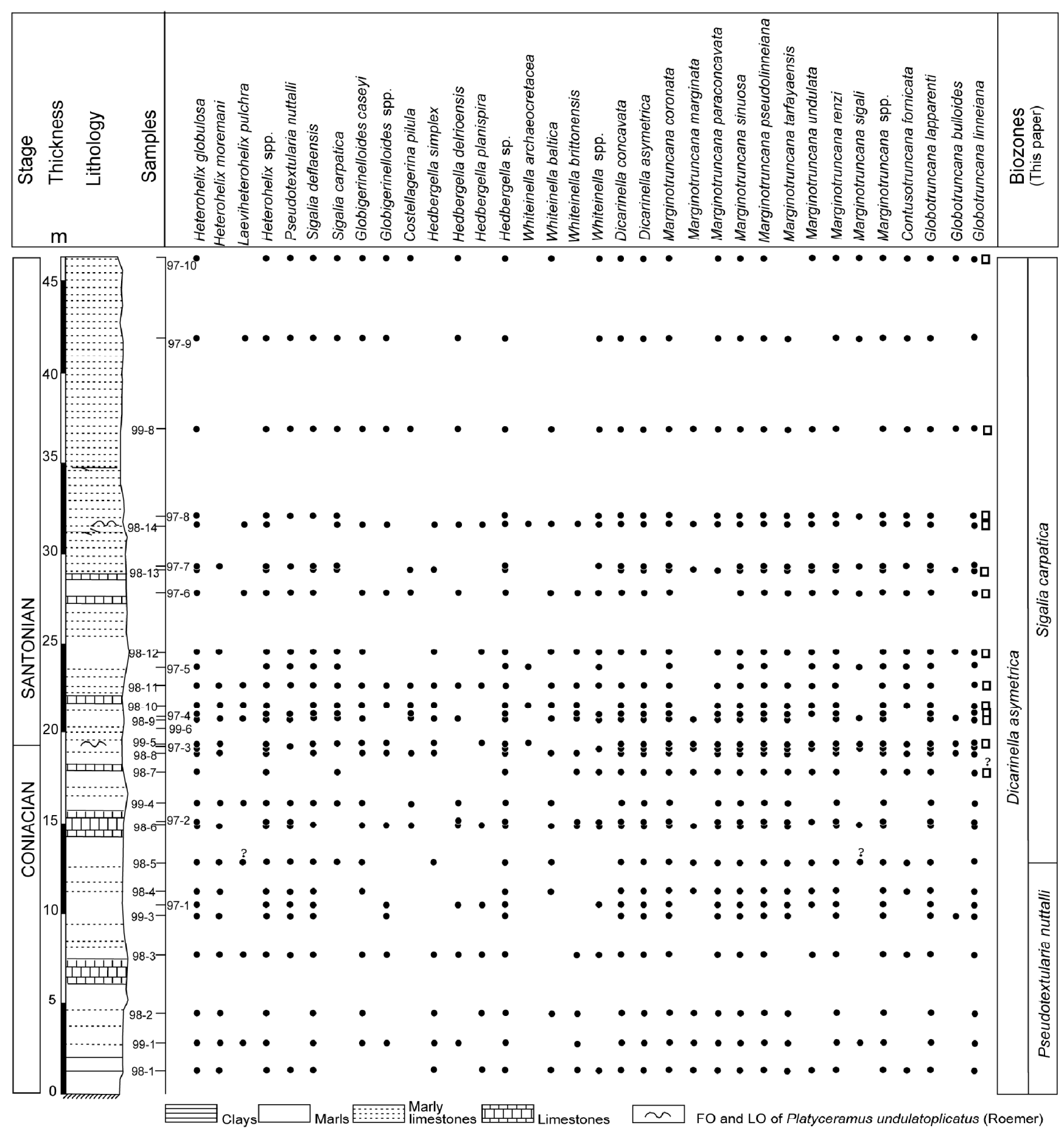

Figure 6. Stratigraphical distribution of planktonic foraminifera and planktonic foraminiferal zonation of the Upper Coniacian and Lower Santonian in the Olazagutia section (small squares indicate occurrences of pillbox-like morphotypes of Globotruncana linneiana (after Lamolda et al., 2007, fig. 2).

nannoconids are also believed to be indicative of low-middle latitudes, rather than high ones.

In contrast, Kamptnerius magnificus and Gartnerago segmentatum, nannofossils recorded infrequently and discontinuously in our samples, and mainly restricted in Olazagutia to the lowermost Santonian, are usually common to abundant at high latitudes (Thierstein, 1976). Svábenická (1995) cited K. magnificus as a coldwater species, too. It is present in the Tethyan Realm, but infrequently, often related to cold-water incursions into lower latitudes (Melinte,
1999). The $\delta^{18} \mathrm{O}$ curve shows higher values in the lowermost Santonian at Olazagutia, overlying a decreasing trend in the uppermost Coniacian and CSB, which is consistent with occurrences of the species cited from temperate regions, mainly at the same levels. This could reflect global climatic changes or a more local effect involving the balance between Tethyan and Atlantic water sources (Lamolda and Paul, 2007).

Also noteworthy is the high abundance of holococcoliths in the section studied. These taxa are believed to be more abundant in 


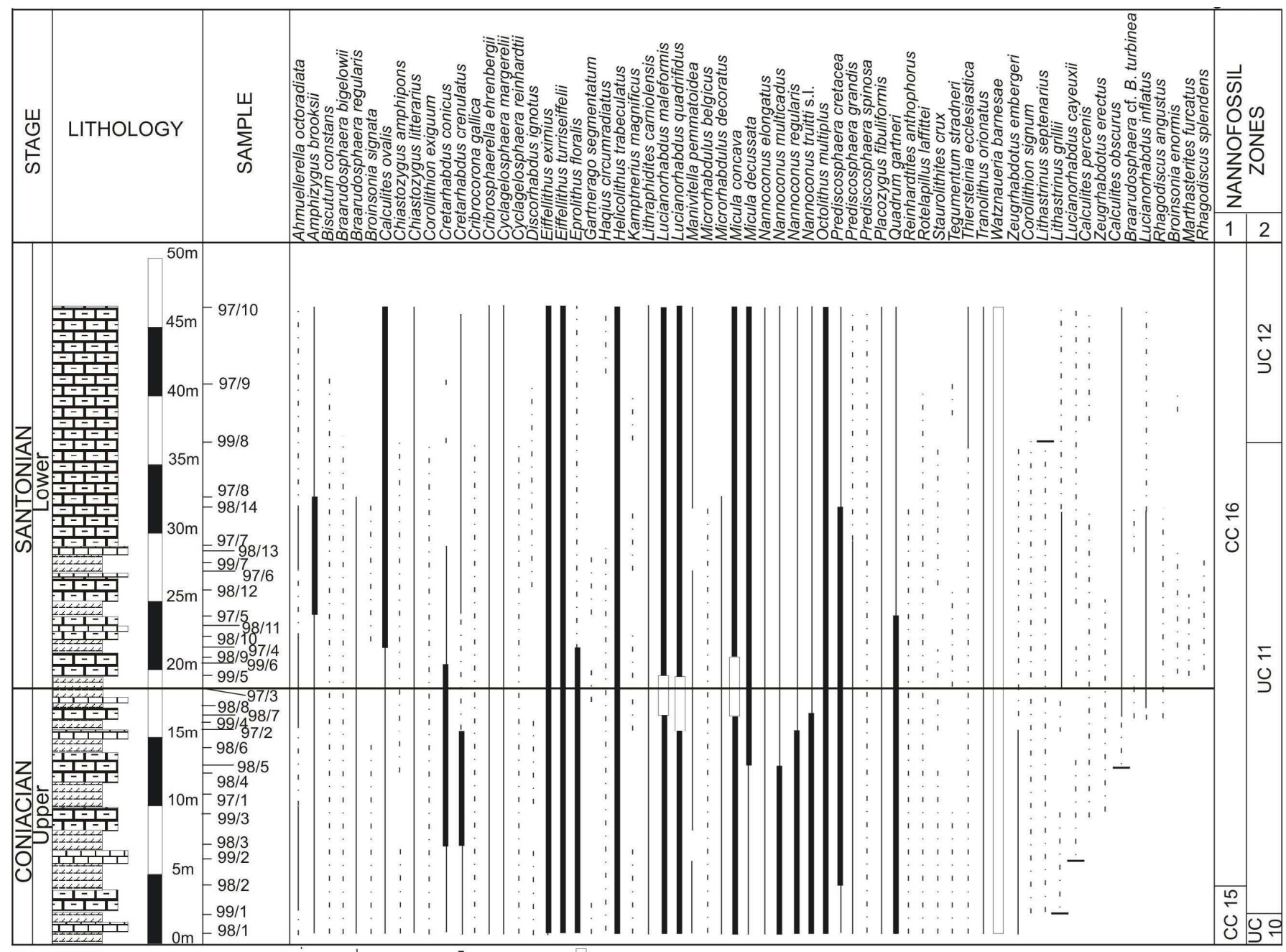

Nannofossil distribution: rare few $\mid$ common I abundant $]$ Nannofossil zones: 1-after Sissingh (1977); 2 - after Burnett (1998)

Figure 7. Range-chart of nannofossil species in the Olazagutia section. Abundances were recorded as follows: abundant, >1 specimen/field of view (FOV); common, 1 specimen/2-10 FOV; few, 1 specimen/11-20 FOV; rare, 1 specimen/>20 FOV (after Melinte and Lamolda, 2002, fig. 2).

nearshore and epicontinental areas than in open oceans (Thierstein, 1976; Perch-Nielsen, 1985). This observation is consistent with the palaeogeographical setting of the Olazagutia section, situated in the Navarro-Cantabrian Platform, with sediments deposited on a rapidly sinking shelf.

Planktonic foraminiferal assemblages are typical of the Tethyan Realm, mostly of globotruncanids s.l., whereas globigeriniforms (e.g., Archaeoglobigerina) are usually minor components. The genus Sigalia occurs, especially $S$. carpatica, which characterizes the palaeotropics between the Atlantic and southern Tibet. Interestingly, the occurrence of benthic foraminifera, mainly Neoflabellina and Stensioeina, allows a correlation with the temperate northern region, especially in the CSB interval.

The inoceramid fauna belongs to the southern Euroamerican Province (Kauffman, 1973). In fact, the upper part of the Coniacian in northern Spain, including the southern central Pyrenees, is characterized by a Magadiceramus spp. fauna, and the lowermost Santonian by $P$. undulatoplicatus. No sphenoceramids are known in the region.

In summary, most of the fauna and calcareous nannofossils are cosmopolitan or with a wide palaeogeographic distribution in low and middle latitudes. It is noteworthy that some planktonic foraminifera (e.g., Globotruncana, Costellagerina), and benthic foraminifera (e.g., Neoflabellina, Stensioeina) enable correlation with northern temperate and austral regions.

\section{Access}

The owners of the quarry, Cementos Portland, have agreed to maintain the section and allow access for research (Fig. 1). The GSSP is protected by governmental agreement between the Navarran Regional Government, the Instituto Geológico y Minero de España (Spanish Geological Survey) and the owners.

\section{Overview and discussion of the main fossil groups and events}

\section{Inoceramids}

The geographic distribution of inoceramid species relevant for the CSB highlights a bioprovinciality in their assemblages. The primary marker Platyceramus undulatoplicatus (Fig. 10) has a wide geographic distribution, but it is not known in the Boreal, nor in the 


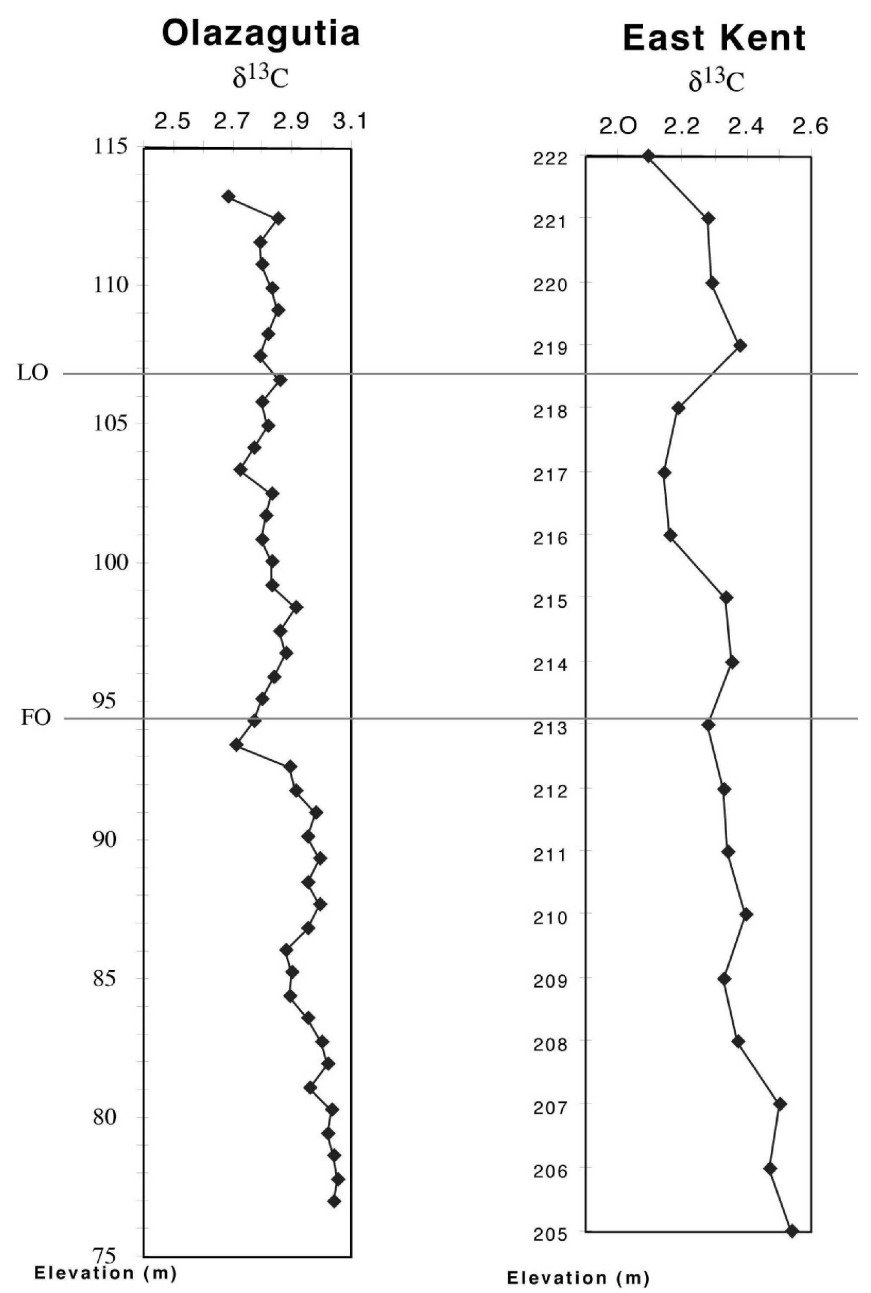

Figure 8. Carbon isotope curve for the Olazagutia section and suggested correlation with East Kent (data from Jenkyns et al., 1994). Horizontal lines indicate positions of the first (FO) and last (LO) occurrences of Platyceramus undulatoplicatus (Roemer), which have been used to calibrate relative sedimentation rates at the two sections (after Lamolda and Paul, 2007, fig. 3).
Pacific realms. The FOs of Platyceramus cycloides and subspecies seem to be good proxies for the CSB, in the absence of $P$. undulatoplicatus. They occur in North Africa, where they used to be the marker for the local CSB. They co-occur with P. undulatoplicatus in Ten Mile Creek, northern Spain (Gale et al. 2007, Gallemí et al. 2007), northern Germany (López et al., 1992), and Austria (Tröger and Summesberger, 1994). The LO of Magadiceramus spp. is not a good proxy for the CSB, as it has been recorded well below the FO of P. undulatoplicatus. The FO of Cordiceramus cordiformis, in the lower part of the Santonian, could help in recognizing of the CSB, as this species co-occurs with $P$. undulatoplicatus in northern Spain and at Ten Mile Creek. It is also known from the lower part of the Santonian in Germany. In the Boreal Realm, the FO of the Volviceramus cardissoides-pachti group may be a good proxy for the CSB (Tröger 1989).

\section{Ammonites}

Most ammonite species occurring across the Coniacian/Santonian transition are not cosmopolitan. Nevertheless, they allow a biozonation from the middle Coniacian to the middle Santonian. The LO of the late Coniacian species Protexanites bourgeoisi, which has a wide geographical distribution, is not a proxy for the CSB as its known records lie well below the FO of $P$. undulatoplicatus. Several species of Hemitissotia have their LOs close to and above the FO of $P$. undulatoplicatus in northern Spain, and they could thus be a proxy for the CSB, but of local interest only. The FO of Kitchinites emscheris may be a good proxy for the CSB, but exclusively in the Münsterland Basin, Germany (Kaplan and Kennedy 2000). The FO of Placenticeras polyopsis in the lowermost Santonian was regarded by Dhondt et al. (2007) as a good proxy for the CSB, but checks of other sections are needed to ascertain whether or not it is a reliable marker.

\section{Planktonic Foraminifera}

Sigalia carpatica (Fig. 11 A-C), the secondary marker of the CSB (Lamolda and Hancock, 1996), is a relatively widespread taxon in the palaeotropics from the Atlantic Ocean to southern Tibet. Both its

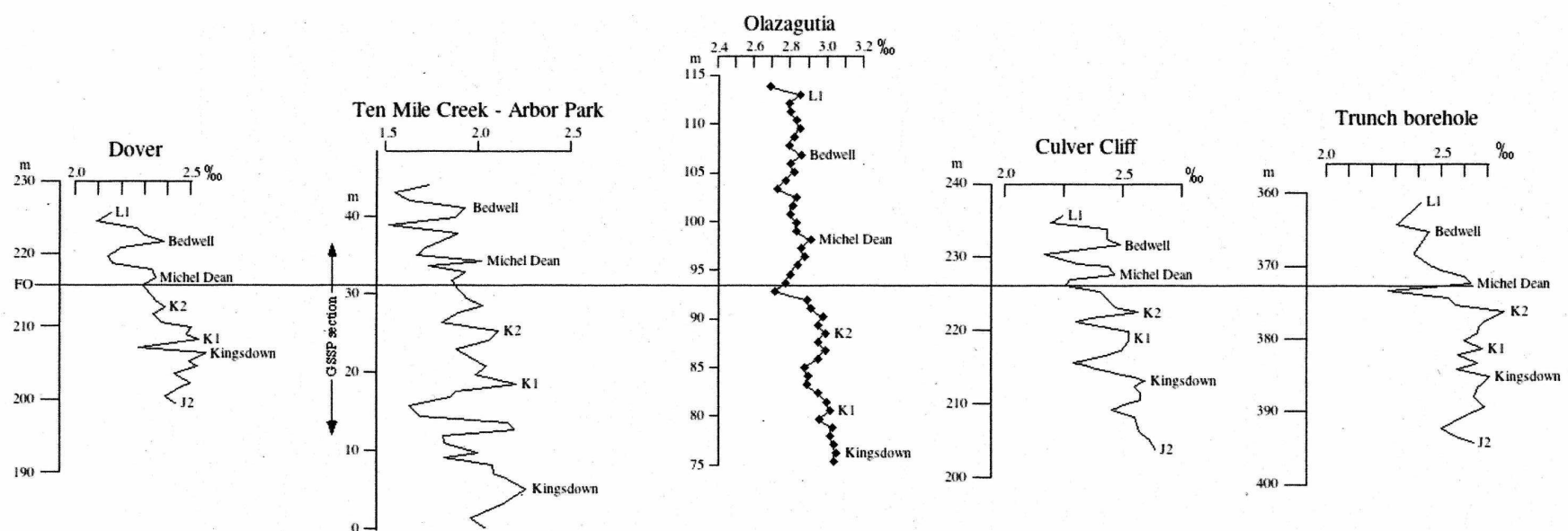

Figure 9. Suggested carbon isotope correlation between three sections in southern England (Dover, Culver Cliff, and the Trunch Borehole), and the two candidate GSSP sections (Ten Mile Creek, Texas and Olazagutia, Spain). FO, first occurrence of Platyceramus undulatoplicatus, the primary biomarker for the base of the Santonian Stage. Vertical line against the Ten Mile Creek-Arbor Park isotope curve indicates the extent of the candidate GSSP section. Note that the vertical scale for the Trunch borehole is in metres below surface (after Paul and Lamolda, 2009, fig. 5). 

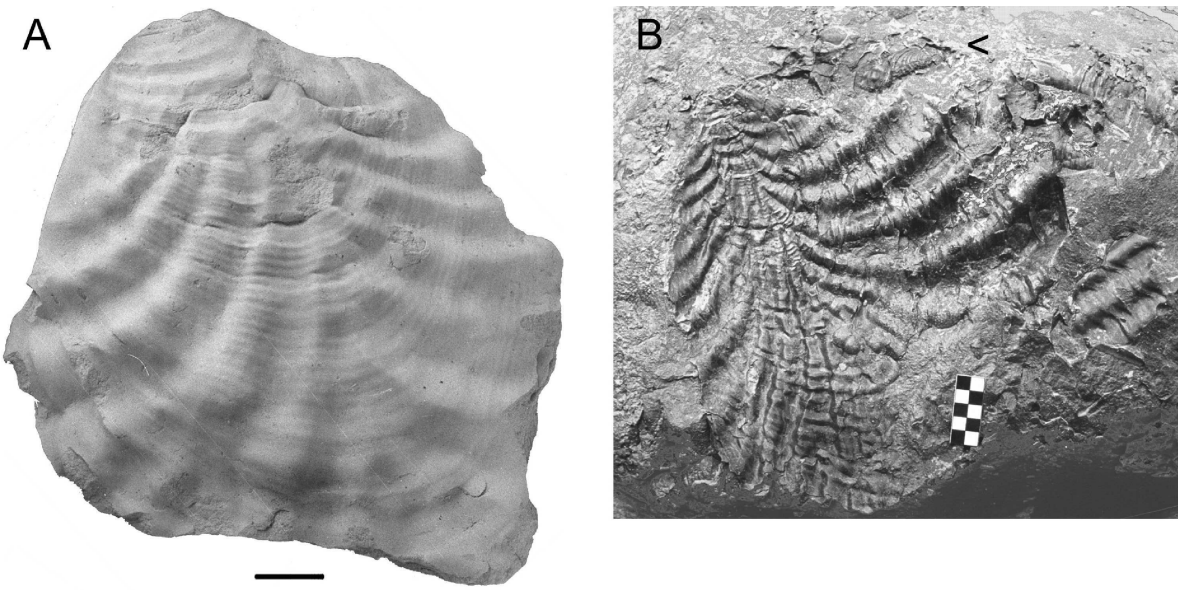

Figure 10. Platyceramus undulatoplicatus (Roemer), the primary marker for the base of the Santonian Stage. A Universitat Autònoma de Barcelona 67000. Found loose. B Field photograph of an uncollected specimen with a juvenile attached (arrowed) from the GSSP section. Scale bars $1 \mathrm{~cm} \mathrm{(A)} \mathrm{and} 5 \mathrm{~cm}(B)$. A whitened with ammonium chloride for photography.

FO and consistent occurrence lie near the CSB, below and above, respectively. The FO of Costellagerina pilula (Fig. 11G, H) is just below the CSB and this widespread species may be an additional useful marker.

The FO of pillbox-like morpho-types of Globotruncana linneiana
(Fig. 11D) is close to the CSB in Europe, both in typical Tethyan and in temperate northern localities. It is a proxy of the CSB to be checked in other regions where neither $P$. undulatoplicatus nor $S$. carpatica are found.

Relatively common occurrences of $D$. asymetrica (Fig. 11F, I) similar to that of $D$. concavata, are known from lowermost Santonian strata at many localities. Nonetheless, it occurs throughout the upper Coniacian at low frequencies. Thus, its first common occurrence may be an additional proxy of the CSB in the palaeotropics, except in shallow-water facies.

\section{Benthic Foraminifera}

The uppermost Coniacian is characterized by the LO of Stensioeina granulata, and the FOs of S. polonica, S. granulata incondita, Cibicides eriksdalensis, and Neoflabellina gibbera. In the lowermost Santonian, S. granulata incondita, C. eriksdalensis, and N. gibbera increase their abundances, and the FOs of Neoflabellina praecursor and $N$. santonica are recorded. All cited species, except the latter two, have a wide geographical distribution, especially in the

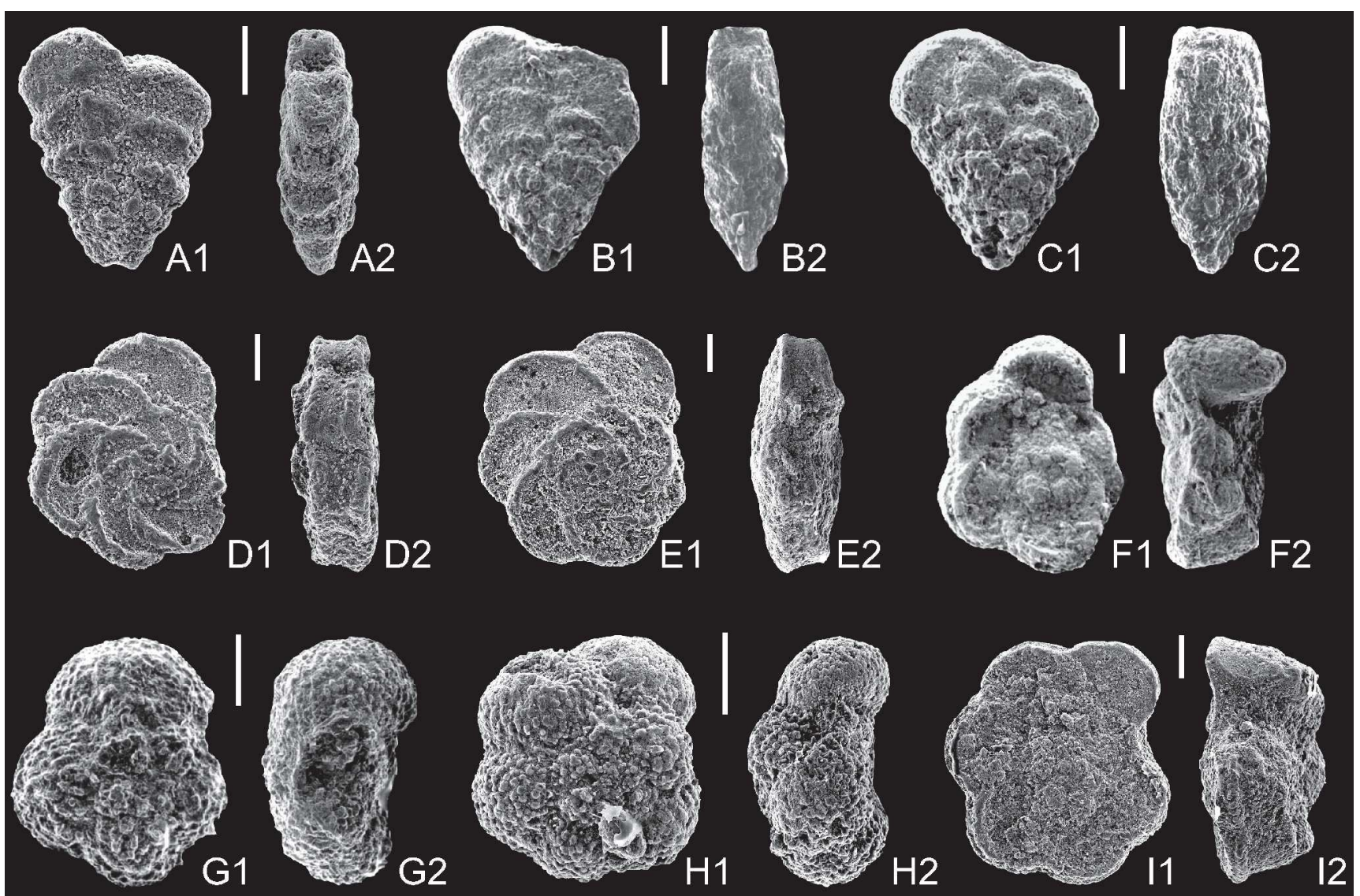

Fig. 11. Planktonic foraminifera from the Cantera de Margas GSSP section. A1-A2 - Sigalia carpatica Salaj and Samuel, sample 98-5; B1B2, C1-C2 - Sigalia carpatica Salaj and Samuel, sample 97-8; D1-D2 - Globotruncana linneiana (d'Orbigny), sample 98-10; E1-E2 Globotruncana linneiana (d'Orbigny), sample 97-4; F1-F2 - Dicarinella asymetrica (Sigal), sample 97-6; G1-G2 - Costellagerina pilula (Belford), sample 97-6; H1-H2 - Costellagerina pilula (Belford), sample 98-10; I1-I2 - Dicarinella asymetrica (Sigal), sample 98-1. Scale bars represent $100 \mu \mathrm{m}$. 
transitional region between the Tethys and Boreal realms. Neoflabellina spp. are known from North America (Texas, USA), the Russian Platform, Western Carpathians, Germany, northern Spain and Tunisia. Thus, they are potentially good indices for the CSB in different paleogeographical areas.

\section{Calcareous Nannoplankton}

The CSB is placed between the FO of Lucianorhabdus cayeuxii and the LO of Lithastrinus septenarius, within the CC16 Zone of Sissingh (1977), and in the UC11c Subzone of Burnett (1998). Above the FO of L. cayeuxii a consistent occurrence of Calculites obscurus is noted, which in other localities is recorded as its local FO. Another nannofossil event identified in northern Spain, Austria and southern Romania that could be further checked for its reliability in other sections, is an increase of holococcoliths sometimes associated with the FO of Lucianorhabdus inflatus, above the FO of Lucianorhabdus cayeuxii and below the CSB. In addition, a reliable event could be a higher abundance of Micula concava, which occurs across the CSB.

\section{Carbon Stable Isotopes}

Carbon stable isotope curves have been published for the two candidate sections for the Coniacian-Santonian boundary GSSP (Gale et al. 2007; Lamolda and Paul 2007). In addition, Jarvis et al. (2006) published several curves covering the same interval for sections in southern England in which they name a series of carbon isotope events. Those isotope events are always local maxima, (i.e., peaks) in the carbon isotope curve, but the intervening minima (troughs) may also be used in correlation (Paul and Lamolda 2009). The correlation of the isotope events in England is further supported by very detailed bio- and lithostratigraphy. Jarvis et al. (2006) listed 45 bioevents between the base of the Cenomanian and the top of the Campanian, and over 30 lithological marker horizons used for detailed correlation. These sections in southern England provide an international standard for carbon isotope correlation of the Cenomanian through the Campanian. Gale et al. (2007) were able to correlate some of the isotope events recognized by Jarvis et al. (2006) in the sections at Ten Mile Creek and Arbor Park, Texas, and to relate these to other bioevents in the Ten Mile Creek. Paul and Lamolda (2009) suggested correlations of the carbon isotope events recognized by Jarvis et al. (2006) in southern England with those at both Olazagutia and Ten Mile Creek (Fig. 9).

Carbon stable isotope events permit long-distance correlation, even between quite different palaeoenvironments and biogeoprovinces. Takashima et al. (2010) provided a good example of correlation between Upper Cretaceous $\mathrm{C}_{\text {org }}$ stable isotopes of terrestrial origin (wood) from North Hokkaido, Japan, and classic localities in S England and Central Italy (marine carbonates). Correlation of eight carbon stable isotope events since the early Coniacian Navigation event to late Santonian Hawks Brow event provides new insights about the location of the CSB with respect to macro- and microfossil biozonations. In fact, the FO of Inoceramus amakusensis used as biomarker of the CSB in North Japan and Far East Russia is found close to and above the Navigation event instead of the Michel Dean event, as would be expected using carbon stable isotope stratigraphy (Jarvis et al., 2006; Paul and Lamolda, 2009). Therefore, the FO of I. amakusensis is early Coniacian in age. In this case, a proxy for the CSB in North Japan could be the local FO of the planktonic foraminifer Contusotruncana fornicata.

Wendler et al. (2011) proposed a correlation between the pelagic Upper Cretaceous from southern Tibet (southern border of the Tethys ocean) with chalks from southern England and northern Germany, in the Boreal Realm, studied by Jarvis et al. (2006) and Voigt et al. (2010), respectively. Wendler et al. (2011) recognized six carbon stable isotope events between the middle Coniacian $\mathrm{J} 2$ event and the late Santonian Hawks Brow event in the Tingri section. The local FO of D. asymetrica is consistent with its FO in Romania, as it is close and above the middle Coniacian J2 event, and is below the upper Coniacian Kingsdown event. The local FO of $S$. carpatica is consistent with its common occurrence in the lower Santonian everywhere. Interestingly, bioevents and/or stable isotope events allow recognition of the CSB at those localities despite the absence of the primary marker, $P$. undulatoplicatus.

\section{Cyclostratigraphy and geochronology}

As mentioned above under lithostratigraphy, it appears possible to distinguish about five decametric cycles across the CSB in the Olazagutia section. Whether or not these cycles can be correlated to other localities, e.g., the Niobrara Formation, Western Interior, USA (Locklair and Sageman, 2008) is unknown. Those authors proposed a $400 \mathrm{kyr}$-cycle series, allowing the identification of both the current and previously accepted local CSB. Although the Western Interior shows an endemic macrofauna, especially ammonites, those results are a good point of reference for further research. According to Gradstein et al. (2012) the CSB is 86.26 $\pm 0.12 / 0.49 \mathrm{Ma}$ in age.

\section{The sequence of events across the Coniacian-Santonian transition in Olazagutia}

The results discussed above enable recognition of the sequence of events across the Coniacian-Santonian transition along the eastern border of the "Cantera de Margas" quarry (Olazagutia). These are, in stratigraphic order from oldest (1) to youngest (20). Potentially reliable events (Paul and Lamolda 2009) are shown bold, other events previously considered relevant are underlined.

20 - The LO of Lithastrinus septenarius at the $112.4 \mathrm{~m}$ level.

19 - The Bedwell $\delta^{13} \mathrm{C}$ stable carbon isotope event at the $106.75 \mathrm{~m}$ level.

18 - The LO of Platyceramus undulatoplicatus at the $105.9 \mathrm{~m}$ level.

17 - The FO of Platyceramus cycloides at the $99.1 \mathrm{~m}$ level.

16 - The Michel Dean $\delta^{13} \mathrm{C}$ stable carbon isotope event and consistent occurrence of Sigalia carpatica at the $98.6 \mathrm{~m}$ level.

15 - The FO of Neoflabellina praecursor and the first common occurrence of Dicarinella asymetrica at the $95.8 \mathrm{~m}$ level.

14 - The FO of the pillbox-like morphotypes of Globotruncana linneiana at the $94.5 \mathrm{~m}$ level.

13 - The FO of Platyceramus undulatoplicatus at the $94.4 \mathrm{~m}$ level.

$\underline{12}$ - The FO of abundant Micula concava at the $93.8 \mathrm{~m}$ level.

11 - The FOs of Neoflabellina gibbera and Lucianorhabdus inflatus, and the FO of abundant holococcoliths at the $92.6 \mathrm{~m}$ level. 
10 - The Peak $3 \delta^{13} \mathrm{C}$ stable carbon isotope event at the $90.85 \mathrm{~m}$ level.

9 - The FO of Costellagerina pilula at the $90.4 \mathrm{~m}$ level.

8 - The Peak K2 upper $\delta{ }^{13} \mathrm{C}$ stable carbon isotope event at the $89.45 \mathrm{~m}$ level.

7 - The Peak K2 lower $\delta^{13} \mathrm{C}$ stable carbon isotope event at the $87.45 \mathrm{~m}$ level.

6 - The FOs of Sigalia carpatica and Calculites obscurus at the $87.4 \mathrm{~m}$ level.

5 - The FO of Lucianorhabdus cayeuxii at the $81.9 \mathrm{~m}$ level.

4 - The Peak $\mathrm{K} 1 \delta^{13} \mathrm{C}$ stable carbon isotope event at the $81.6 \mathrm{~m}$ level.

3 - The FO of Lithastrinus grillii at the 79.9 m level.

2 - The Kingsdown $\delta^{13} \mathrm{C}$ stable carbon isotope event at the $77.2 \mathrm{~m}$ level.

1 - The FO of Magadiceramus subquadratus at $64.6 \mathrm{~m}$ level.

\section{Summary}

- The "Cantera de Margas" section has a continuous exposure, along its eastern border, through about $160 \mathrm{~m}$, from the middle Coniacian to the middle Santonian.

- The GSSP for the base of the Santonian Stage lies at $94.4 \mathrm{~m}$, marked by the first occurrence of the inoceramid Platyceramus undulatoplicatus, which occurs through $11.5 \mathrm{~m}$, and is very common in the first $2 \mathrm{~m}$.

- The CSB is bracketed by Peak 3 and the Michel Dean $\delta{ }^{13} \mathrm{C}$ stable carbon isotope events, $3.55 \mathrm{~m}$ below and $4.4 \mathrm{~m}$ above the CSB, respectively. The CSB lies immediately above the $\delta{ }^{13} \mathrm{C}$ minimum between these two peaks.

- Graphic correlation of stable carbon isotope events is one of the most accurate tools for international correlation (Paul and Lamolda 2009). It allows calibration of bioevents, plus distinction of which are good time planes and which are not. It should be a standard procedure in selecting GSSPs.

- Only four bioevents appear to be reliable as time planes: both the FO and LO of $P$. undulatoplicatus, the FO of the nannofossil Lucianorhabdus cayeuxii, and the FO of the inoceramid Platyceramus cycloides. The latter is also a good proxy for the CSB.

- In the critical interval, e.g., between the FO of the planktonic foraminifer Sigalia carpatica, $7 \mathrm{~m}$ below the CSB and the FO of P. cycloides, $4.7 \mathrm{~m}$ above the $\mathrm{CSB}$, there are 10 additional notable bioevents to characterize the CSB interval. These allow correlation of Olazagutia with northern and southern temperate provinces, in addition to Tethyan localities.

\section{Acknowledgements}

We are grateful to the owners, Cementos Portland, for unlimited access to the quarry for research and for the original version of Fig. $1 \mathrm{~B}$, showing permitted access. We also thank especially Jaume Gallemí, Jana Ion, Gregorio López, Ludmila F. Kopaevich, Ricard Martínez, Mihaela C. Melinte-Dobrinescu, Seiichi Toshimitsu, and Elena Jagt-Yazykova, all of them members of the Santonian Working Group, for their help in preparing the proposal. Reviews by J. W. M. Jagt, H. Nishi and M. Wagreich significantly improved the initial version of the manuscript.

\section{References}

Amiot, M., 1982. El Cretácico Superior de la Región Navarro-Cántabra, in García, A. (Coord.), El Cretácico de España. Universidad Complutense, Madrid, pp. 88-111.

Amiot, M., Floquet, M., and Mathey, B., 1983. Relations entre les trois domaines de sédimentation. In: Vue sur le Crétacé basco-cantabrique et nord-ibérique. Mémoires Géologiques Université Dijon, v. 9, pp. 169175

Birkelund, T., Hancock, J.M., Hart, M.B., Rawson, P.F., Remane, J., Robaszynski, F., Schmid, F., and Surlyk, F., 1984. Cretaceous stage boundaries-Proposals. Bulletin of the Geological Society of Denmark, v. 33, pp. 3-20

Burnett, J.A., 1998. Upper Cretaceous, In: Bown, P.R., ed. Calcareous Nannofossil Biostratigraphy. London, British Micropalaeontological Society Publications Series (Chapman and Hall Ltd/Kluwer Academic Press), pp. 132-199.

Coquand, H., 1857. Position des Ostrea columba et biauriculata dans le groupe de la craie inférieure. Bulletin de la Société géologique de France, v. 2 no.4, pp. 745-766

Dhondt, A.V., Lamolda, M.A., and Pons, J.M., 2007. Stratigraphy of the Coniacian-Santonian transition. Cretaceous Research, v. 28, pp. 1-4.

Gale, A.S., Kennedy, J.W., Lees, J.A., Petrizzo, M.R., and Walaszczyk, I., 2007. An integrated study (inoceramid bivalves, ammonites, calcareous nannofossils, planktonic foraminifera, stable carbon isotopes) of the Ten Mile Creek section, Lancaster, Dallas County, north Texas, a candidate Global boundary Stratotype Section and Point for the base of the Santonian Stage. Acta Geologica Polonica, v. 57, pp. 113-160.

Gallemí, J., López, G., Martínez, R., and Pons, J.M., 2007. Macrofauna of the Cantera de Margas Section, Olazagutia (Coniacian/Santonian boundary, Navarro Cantabrian Basin, N Spain). Cretaceous Research, v. 28 , pp. 5-17.

Gradstein, F.M., Ogg, J.G., Schmitz, M., and Ogg, G., 2012. The Geological Time Scale 2012, New York, Elsevier, 2 volumes.

Gräfe, K.U., and Wiedmann, J., 1998. Sequence stratigraphy on a carbonate ramp: the late Cretaceous Basco-Cantabrian Basin (northern Spain), in Graciansky, P. C. de, Hardenbol, J., Jacquin, T., and Vail, P.R., eds, Mesozoic and Cenozoic Sequence Stratigraphy of European Basins. SEPM Special Publication, no. 60, pp. 333-341.

Hancock, J.M., 1991. Ammonite scales for the Cretaceous System. Cretaceous Research, v. 12, pp. 259-291.

Harland, W.B., Armstrong, R.L., Cox, A.V., Craig, L.E., Smith, A.G., and Smith, D.G., 1989. A Geologic Time Scale 1989. London, The British Petroleum Company plc.

Howe, R.W., Sikora, P.J., Gale, A.S., and Bergen, J.A., 2007. Calcareous nannofossil and planktonic foraminiferal biostratigraphy of proposed stratotypes for the Coniacian/Santonian boundary: Olazagutia, northern Spain; Seaford Head, southern England; and Ten Mile Creek, Texas, USA. Cretaceous Research, v. 28, pp. 61-92.

Jarvis, I., Gale, A.S., Jenkyns, H.C., and Pearce, A., 2006. Secular variation in Late Cretaceous carbon isotopes: a new $\delta^{13} \mathrm{C}$ carbonate reference curve for the Cenomanian-Campanian (99.6-70.6 Ma). Geological Magazine, v. 143, pp. 561-608.

Jenkyns, H. C., Gale, A. S., and Corfield, R. M., 1994. Carbon- and Oxygenisotope stratigraphy of the English Chalk and Italian Scaglia and its palaeoclimatic significance. Geological Magazine, v. 131, pp. 1-34.

Kannenberg, M., 1985. Stratigraphische Arbeiten in der Kreide der westlichen Barranca in Navarra, Nordspanien und statistische Untersuchungen der Echiniden-Gattung Micraster im Steinbruch Olazagutia (ConiacCampan). Diplom Thesis, Freie Universität Berlin, 100 pp.

Kaplan, U., and Kennedy, W.J., 2000. Santonian ammonite stratigraphy of the Münster Basin, NW Germany. Acta Palaeontologica Polonica, v. 50, pp. 99-117.

Kauffman, E.G., 1973. The Upper Cretaceous Inoceramus of Puerto Rico. Transactions of the Fourth Caribbean Geological Conference, Trinidad 1965, pp. 203-218. 
Küchler, T., 2002. Additional macrofossil biostratigraphic data on the Upper Coniacian and Santonian of the Olazagutia, Iturmendi and Zuazu sections in the Barranca (Navarra), northern Spain, in Wagreich, M. (Ed.), Aspects of Cretaceous Stratigraphy and Palaeobiogeography. Österreichische Akademie der Wissenschaften, Schriftenreihe der Erdwissenschaftlichen Kommissionen, v. 15, pp. 315-331.

Lamolda, M. A., and Hancock, J.M., 1996. The Santonian Stage and substages, in P.F. Rawson, A.V. Dhondt, J.M. Hancock and W.J. Kennedy, eds, Proceedings ,Second International Symposium on Cretaceous Stage Boundaries“ Brussels 8-16 September, 1995. Bulletin de l'Institut Royal des Sciences Naturelles de Belgique, Sciences de la Terre, v. 66-suppl., pp. 95-102.

Lamolda, M.A., and Paul, C.R.C., 2007. Carbon and Oxygen Stable Isotopes across the Coniacian-Santonian boundary at Olazagutia, N. Spain. Cretaceous Research, v. 28, pp. 37-45.

Lamolda, M.A., Melinte, M.C., and Peryt, D., 1999. Datos micropaleontológicos preliminaries sobre el límite Coniaciense-Santoniense en Olazagutía (Navarra, España). Revista Española de Micropaleontología, v. 31, pp. 337-345.

Lamolda, M.A., Peryt, D., and Ion, J., 2007. Planktonic foraminiferal bioevents in the Coniacian/Santonian boundary interval at Olazagutia (Navarra province), Spain. Cretaceous Research, v. 28, pp. 18-29.

Locklair, R.E., and Sageman, B.B., 2008. Cyclostratigraphy of the Upper Cretaceous Niobrara Formation, Western Interior, U.S.A.: A ConiacianSantonian orbital timescale. Earth and Planetary Science Letters, v. 269, pp. 540-553.

López, G., Lamolda, M.A., and Martínez, R. (1992). Biogeographic aspects of the Coniacian and Santonian inoceramids (Bivalvia) in northern Spain: Their Tethyan affinities. Palaeogeography, Palaeoclimatology, Palaeoecology, v. 92, pp. 249-261.

Melinte, M., 1999. Turonian-Coniacian nannofossil events in the East and South Carpathians (Romania). Revista Española de Micropaleontología, v. 31, pp. 369-377.

Melinte M.C., and Lamolda M.A., 2002. Calcareous nannofossils around the Coniacian/Santonian boundary in the Olazagutia section (N. Spain), in Wagreich, M. ed., Aspects of Cretaceous stratigraphy and palaeobiogeography. Österreichische Akademie der Wissenschaften, Schriftenreihe der Erdwissenschaftlichen Kommissionen, v. 15, pp. 351-364.

Melinte M.C., and Lamolda M.A., 2007. Calcareous nannofossil biostratigraphy of the Coniacian/Santonian boundary interval in Romania and comparison with other European regions. Cretaceous Research, v. 28, pp. 119-127.

Nederbragt, A.J., 1990. Biostratigraphy and paleoceanographic potential of the Cretaceous planktic foraminifera Heterohelicidae. Ph.D. thesis. Centrale Huisdrukkerij Vrije Universiteit, Amsterdam, 204 pp.

Paul, C.R.C., and Lamolda, M.A., 2009. Testing the precision of bioevents. Geological Magazine, v. 146, pp. 625-637.

Perch-Nielsen, K, 1985. Mesozoic calcareous nannofossils, in Bolli, H.M., Saunders, J.B., Perch-Nielsen, K. eds, Plankton Stratigraphy. Cambridge, Cambridge University Press, pp. 329-426.

Peryt, D., and Lamolda, M.A., 2007. Neoflabellinids (benthic foraminifers) from the Upper Coniacian and Lower Santonian at Olazagutia, Navarra province, Spain; taxonomy and correlation potential. Cretaceous Research, v. 28, pp. 30-36.

Ramírez del Pozo, J. 1971. Bioestratigrafía y microfacies del Jurásico y Cretácico del Norte de España (Región Cantábrica). Memorias del Instituto Geológico y Minero de España, v. 78, pp. 1-357.

Sissingh, W., 1977. Biostratigraphy of Cretaceous calcareous nannoplankton. Geologie en Mijnbouw, v. 56, pp. 37-65.

Svábenická, L., 1995 Common occurrences of the ecologically restricted nannofossils in the Campanian sediments of the Zdánice Unit and Waschberg Zone, West Carpathians. - Proceedings XVth Congress CarpathoBalkan Geological Association, Geological Society of Greece Special Publication, no. 4, pp. 282-287.

Takashima, R., Nishi, H., Yamanaka, T., Hayashi, K., Waseda, A., Obuse, A., Tomosugy, T., Deguchi, N., and Mochizuki, S., 2010. High-resolution terrestrial carbon isotope and planktic foraminiferal records of the Upper Cenomanian to the Lower Campanian in the Northwest Pacific. Earth and Planetary Science Letters, v. 289, pp. 570-582.

Thierstein, H.R. 1976. Mesozoic calcareous nannoplankton biostratigraphy of marine sediments. Marine Micropaleontology, v. 1, pp. 325-362.

Thierstein, H.R. 1981. Late Cretaceous nannoplankton and the change at the Cretaceous/Tertiary boundary. SEPM Special Publication, no. 32, pp. 355-394.

Tröger, K.-A., 1989. Problems of Upper Cretaceous inoceramid biostratigraphy and palaeogeography in Europe and western Asia. In: Cretaceous of the Western Tethys, Proceedings of the $3^{\text {rd }}$ International Cretaceous Symposium, Tübingen 1987 (J. Wiedmann, Ed.). E. Schweizerbart'sche Verlagsbuchhandlung, Stuttgart. 911-930.

Tröger, K.-A., and Summesberger, H., 1994. Coniacian and Santonian inoceramid bivalves from the Gosau-Group (Cretaceous, Austria) and their biostratigraphic and palaeobiogeographic significance. Annalen des Naturhistorischen Museums in Wien, v. 96A, pp. 161-197.

Varol, O., 1992. Taxonomic revision of the Polycyclolithaceae and its contribution to Cretaceous biostratigraphy. Newsletters on Stratigraphy, v. 27, no 3, pp. 93-127.

Voigt, S., Friedrich, O., Norris, R.D., and Schoenfeld, J., 2010. CampanianMaastrichtian carbon isotope stratigraphy: shelf-ocean correlation between the European shelf sea and the tropical Pacific Ocean. Newsletters on Stratigraphy, v. 44, pp. 57-72.

Wendler, I., Willems, H., Gräfe, K-U., Ding, L., and Luo, H., 2011. Upper Cretaceous inter-hemispheric correlation between the Southern Tethys and the Boreal: chemo- and biostratigraphy and paleoclimatic reconstructions from a new section in the Tethys Himalaya, S-Tibet. Newsletters on Stratigraphy, v. 44, pp. 137-171.

Wiedmann, J., Reitner, J., Engeser, T., and Schwenkte, W., 1983. Plattentektonik, Fazies und Subsidenzgeschichte des basko-kantabrischen Kontinentalrandes während Kreide und Alttertiär. Zitteliana, v. 10, pp. 207-244.

Zander, J., 1988. Die Ober-Kreide der Barranca im Raum Alsasua (Provinz Navarra, Nordspanien), aus mikropaläontologischer Sicht. Unpublished Diploma Thesis, FU Berlin, 127 pp. 